\title{
wrunatestit When the International Lawyers Get to Be Heard - The Story of Tax Treaty Interpretation as Told in Sweden ${ }^{\star}$
}

DOI 10.1515/ntaxj-2016-0004

Received Apr 11, 2016; accepted Apr 12, 2016

\section{Introduction}

At the time of writing, Sweden is a party to approximately 80 bilateral tax treaties. ${ }^{1}$ When concluding tax treaties with each other, states assume obligations and acquire rights under international law. For example, according to a treaty for the avoidance of double taxation concluded between Sweden and Macedonia in 1998, ${ }^{2}$ Sweden owes an obligation to Macedonia to ensure that physical and legal persons resident in Sweden are not taxed for dividends on shares paid by a company resident in Macedonia. Macedonia owes a corresponding obligation to Sweden to ensure that physical and legal persons resident in Macedonia are not taxed for dividends on shares paid by a company resident in Sweden. ${ }^{3}$ So understood, a breach of tax treaty obligations is no different than just any violation of international law. If Sweden does not fulfil all obligations owed to Macedonia, Macedonia is entitled as an injured state to invoke the international responsibility of Sweden. Similarly, if Macedonia does not fulfil all obligations owed to Sweden, Sweden is entitled to invoke the international responsibility of Macedonia. These are the effects of a tax treaty under international law: the injured party is entitled to require that the other party ceases immediately the act

Ulf Linderfalk: Professor of International Law at the Faculty of Law, Lund University, Sweden. Editor-in-Chief of the Nordic Journal of International Law

* Special thanks go to the Torsten Söderberg and Ragnar Söderberg Foundations for the financial support needed to complete this article. 1 Cf. Skatteverket, Rättslig vägledning, http://www4.skatteverket. se/rattsligvagledning, Search path: "Regler och ställningstaganden", last visited on 19 September 2015.

2 Sveriges överenskommelser med främmande makt 1998:26.

3 Cf. Article 10. or acts constituting the breach, if still continuing; the injured party is entitled to demand assurances and guarantees of non repetition of the breach; it is entitled to require reparation, including pecuniary compensation. ${ }^{4}$

No tax treaty concluded by Sweden establishes rights for physical and legal persons resident in the country. According to the approach taken in Sweden to the issue of the relationship between international and domestic law, tax treaties acquire effect domestically due only to an act of incorporation. This is to say, Parliament has to adopt a law containing a text similar to that of the Act (1998:258) concerning the Double Taxation Agreement between Sweden and Macedonia:

The agreement for the avoidance of double taxation on income and capital signed by Sweden and Macedonia, on 17 February 1998, shall apply as law in this country. ${ }^{5}$

Thus, irrespective of the obligations owed by Sweden and Macedonia to each other under international law, it was not until the 1998 Act of Parliament entered into force that physical and legal persons resident in Sweden could claim tax relief for dividends on shares paid by a company resident in Macedonia. ${ }^{6}$ The example highlights the importance of clearly distinguishing, on the one hand, the effects stemming from a tax treaty under international law and, on the other hand, the subsequent effects of the treaty on the application of Swedish tax law. ${ }^{7}$

4 See Articles on Responsibility of States for Internationally Wrongful Acts, UN General Assembly res. 56/83.

5 Modified up until SFS 2011:1390; italics are added. Translation to English by the author. In Swedish, the provision reads: "Det avtal för undvikande av dubbelbeskattning beträffande skatter på inkomst och förmögenhet som Sverige och Makedonien undertecknade den 17 februari 1998 skall gälla som lag här i landet.”

6 Obviously, incorporation entails consequences only on the condition that Swedish tax authorities are entitled to impose tax on such dividends according to other tax legislation.

7 To an international law scholar like myself it appears somewhat peculiar to speak of a dual systemic existence of tax treaties ("skatteavtalets dubbla systematiska hemvist"). See, for example, Berglund (2013, p. 65), Hilling (2014, p. 329), Kleist (2012, p. 48 ff). 
When a tax treaty has been incorporated into the Swedish legal system, however, an intimate relation of substance is created between the treaty and domestic law. This is perfectly illustrated by the quote from the 1998 Act concerning the Double Taxation Agreement between Sweden and Macedonia. Given how Parliament normally chooses to construct a law on incorporation of a tax treaty, the meaning and significance of that law will be wholly dependent on Sweden's international obligations. This means that taxpayers and the Swedish Tax Agency - and by extension, Swedish administrative courts - will sooner or later find themselves engaged in tax treaty interpretation. When the meaning of a tax treaty cannot be established simply by reading its text, no person or authority can say for sure, without having first interpreted the treaty, what precise legal substance was incorporated into Swedish law. ${ }^{8}$ Interpretation of the treaty becomes a means to determine the consequences of the incorporating legislation for the relationship between Swedish taxpayers and the Swedish state.

Scholars at Swedish universities specializing in international taxation seem to agree that when interpreting tax treaties concluded between Sweden and other states, consideration must be had to Articles 31-33 of the $1969 \mathrm{Vi}$ enna Convention on the Law of Treaties (VCLT). ${ }^{9}$ This position coheres with the findings of Swedish administrative courts. In the Luxembourg Case, for example, the Supreme Administrative Court of Sweden held:

The interpretation of double-taxation agreements shall be carried out with a view to determine the common intention of the treaty parties. This intention shall be established by resort to the

\footnotetext{
8 The Vienna Convention makes a distinction between interpreting and understanding a treaty. In the terminology of the Convention, it is fully possible for a person to confer a clear meaning upon the text of a treaty without first engaging in interpretation. I will return to this issue in Section 4.

9 UNTS, Vol. 1155, p. 331. The VCLT applies to treaties concluded between states. It is to be noted that another Vienna Convention on the Law of Treaties was adopted in 1986; it applies to treaties concluded between states and international organizations and between international organizations inter se. UN Doc. A/CONF.129/15. The two Vienna Conventions are sometimes confused. See, for example, Bjuvberg (2015a, p. 113, n. 6) and Bjuvberg (2015b, p. 428, n. 3 and 5). The 1986 Vienna Convention lacks relevance for the interpretation of tax treaties concluded by Sweden with other states, for obvious reasons. In addition, it has not yet entered into force.
}

methods and means referred to in Articles 31-33 in the $1969 \mathrm{Vi}$ enna Convention of the Law of Treaties (SÖ 1975:1). ${ }^{10}$

Consequently, tax-law scholars have had reason to comment repeatedly on the meaning of Articles 31-33 of the VCLT. Their commentary has appeared in various publications. It has covered topics ranging from the significance of party intention for the application of Articles 31-33 and the status of those articles under international law to the possibility of ambulatory interpretation and the extension of fundamental concepts, such as "the object and purpose of a treaty" (Article 31, paragraph 1), and "the special meaning” (Article 31, paragraph 4). ${ }^{11}$ A scholar of international law, and an author of books and numerous articles on treaty interpretation, I have studied this commentary with great interest. I make two observations.

First is the observation that I feel little at home with the picture of the Vienna Convention painted by the taxlaw literature. The understanding of Articles 31-33 represented by the body of Swedish tax-law expertise sits ill with my own collected experience of treaty interpretation in an international law context generally. Second, as a rule, tax-law scholars apply a methodology that differs substantially from the methodology that international lawyers would normally use for finding themselves in a corresponding situation. While international lawyers are trained to establish their assertions regarding the meaning of Articles 31-33 based on the practice of international judicial bodies and international legal literature bearing on the topic, tax-law scholars, to a considerable extent, base their assertions on findings of colleagues active in the same field. Reading Swedish academic literature on international taxation leaves me with the clear impression that the system suffers from something similar to an acoustic feedback. Even if no one seems prepared to supply the basis for recommended understandings of the Vienna Convention, years of repetition have generated widespread acceptance of those same understandings, making criticism exceptionally difficult.

10 RÅ 1996 ref. 84. Translation to English by the author. In Swedish, the passage reads: "Tolkningen av dubbelbeskattningsavtal skall inriktas på att utröna avtalsparternas gemensamma avsikt. Fastställande av vad som utgör den gemensamma partsavsikten skall ske med anlitande av de metoder och medel som anvisas i artiklarna 31-33 i 1969 års Wienkonvention om traktaträtten (SÖ 1975:1).” See, in the same vein, RÅ 1987 ref. 182.

11 See, for example, Berglund (2013, pp. 63-84), Bjuvberg (2015a, pp. 111-130), Bjuvberg (2015b, pp. 427-443), Cejie (2010, pp. 79-98), Dahlberg (2003, pp. 137-155), Dahlberg (2014, pp. 249-271), Hilling (2014, pp. 322-340), Kleist (2012, pp. 47-123), and Sallander (2013, pp. 51-61). 
There is strong reason to break this negative pattern and let international law doctrine take its rightful place on the scene. As I firmly believe, cross-disciplinary dialogue is needed to bring the discussion on tax treaty interpretation entertained in the camp of Swedish tax-law expertise on a more constructive course. It is precisely for this reason that I have written this article. Consequently, I will use this article to highlight a total of 11 assumptions about Articles 31-33 that I have found to be well represented and/or influential in Swedish tax-law literature. I will offer assessment of all 11 assumptions viewed from the perspective of the current practice of international courts and tribunals and the work of international legal scholars. It is my sincere hope that this will help open the door to a more general dialogue between tax-law and international law expertise.

The article will be organized so that each of the 11 assumption corresponds to a separate section. I will use a methodology tailored to suit its purpose. It should be clearly understood that in writing this article, I have no intention to criticise the work of any single tax-law scholar. What I wish to stress is what I conceive to be a failure of an entire system. For this reason, I will approach my task as typically legal scholars do when analyzing and assessing a highlighted proposition rather than its utterance by some particular person or institution at some particular occasion. I will introduce each section with a statement, which in a verbally condensed form captures the well-represented and/or influential assumption to be commented upon. To ensure that statements are not perceived as direct quotes, they will be put using italics.

\section{Articles 31-33 reflect customary international law}

\section{Articles 31-33 are relevant for the interpretation of tax treaties concluded by Sweden with other states because they reflect customary international law. ${ }^{12}$}

Before Articles 31-33 of the VCLT can be applied for the purpose of the interpretation of a tax treaty between any two states (A and $\mathrm{B}$ ), two conditions must be met: $\mathrm{A}$ and $\mathrm{B}$ must be parties to the VCLT and the tax treaty must have been concluded by $\mathrm{A}$ and $\mathrm{B}$ after the point in time when the

12 See Berglund (2013, p. 65, n. 130), Cejie (2010, p. 88), Dahlberg (2003, p. 139, n. 9), and Kleist (2012, p. 71).
VCLT entered into force between them. ${ }^{13}$ When lawyers interpret tax treaties concluded by Sweden with other states, it is often that the situation then prevailing fails to meet at least one of these two conditions. This is the case, for example, with the double-taxation agreement concluded in 1959 between Sweden and Austria. ${ }^{14}$ Even if Sweden and Austria are indeed parties to the VCLT, the tax treaty was concluded long before the VCLT entered into force between the two states - on 27 January $1980 .{ }^{15}$ In all such cases, interpretation must be carried out on the basis of customary international law.

Since many years, international judicial practice takes for granted that customary rules on treaty interpretation are identical to those contained in the Vienna Convention. ${ }^{16}$ Thus, it would seem to make little practical difference whether, in a concrete case, an interpreter is able to formally apply Articles 31-33 or will have to be content with using the articles as a reflection of customary international law. What lawyers must understand, however, is that Articles 31-33 presumably did not fully reflect customary international law when the Vienna Convention was adopted in 1969. ${ }^{17}$ In any case, a different customary international law existed in 1962, when the International Law Commission (ILC) initiated work aimed to codify international rules on treaty interpretation. If claims are made that the rules laid down in Articles 31-33 of the VCLT are identical with customary rules on treaty interpretation, consequently, this cannot explain why Articles 31-33 are always relevant for the interpretation of tax treaties concluded by Sweden. An additional premise is required; without this premise, lawyers will have great difficulty explaining the relevance of Articles 31-33 for the interpretation of older tax treaties, such as the one between Sweden and Austria. What needs to be added is the proposition that treaties are not to be interpreted according to the customary rules that possibly existed at the time of their conclusion, but according to the

13 Cf. VCLT Article 4. It should be noted that among international legal scholars there has been some disagreement as to precisely how to understand the second condition. See, for example, Thirlway (1972, p. 108) and McDade (1986, pp. 499-511).

14 Sveriges överenskommelser med främmande makt 1959:36. 15 Both Sweden and Austria became parties to the VCLT when it first entered into force, on 27 January 1980. See Multilateral Treaties Deposited with the UN Secretary-General, https://treaties.un. org/pages/ParticipationStatus.aspx.

16 See, for example, Maritime Dispute (Peru v. Chile), Judgment of 27 January 2014, http://www.icj-cij.org, pp. 26-27, para. 57.

17 Notably, it was not until 1994 that the International Court of Justice (ICJ) first recognized explicitly the customary law status of Articles 3133. See Territorial Dispute (Libya/Chad), Judgment of 3 February 1994, ICJ Reports 1994, pp. 21-22, para. 41. 
rules that exist on the occasion of their interpretation. ${ }^{18}$ This follows from the so-called doctrine of inter-temporal law, and especially its second "branch." 19

\section{Objective and subjective interpretation}

While Article 31 is applied for the purpose of establishing the meaning of the text of a treaty (objective interpretation), the purpose of Article 32 is to establish the intentions of the treaty parties (subjective interpretation). This is to say that the text of a treaty shall have priority over the intentions of its parties. ${ }^{20}$

The ordinary meaning conferred by Swedish lawyers on the terms "objective" and "subjective" interpretation is commented upon by Professor Stig Strömholm:

An important distinction that should be noted in this context, as it is still commonly upheld in discussion on legal interpretation, is that between 'subjective' and 'objective' method of interpretation. In very general terms, 'subjective interpretation' can be said to refer to a method characterized by the aim of establishing and finding guidance in the purposes and intentions that actually existed at the time of the creation of a law (it is this emphasis on the 'historical law-maker' that justifies the use of the term 'subjective'). An 'objective' method, on the other hand, is characterized by its proponents attempting to find guidance, not in any

18 See, for example, Navigational and Related Rights (Costa Rica v. Nicaragua), Judgment of 13 July 2009, ICJ Reports 2009, p. 237, para. 47.

19 See Island of Palmas Arbitration, Award of 4 April 1928, UNRIAA, Vol. 2, p. 845: "[A] juridical fact must be appreciated in the light of the law contemporary with it, and not of the law in force at the time when a dispute in regard to it arises or falls to be settled ... As regards the question which of different legal systems prevailing at successive periods is to be applied in a particular case (the so-called intertemporal law), a distinction must be made between the creation of rights and the existence of rights. The same principle which subjects the acts creative of a right to the law in force at the time the right arises demands that the existence of the right, in other words its continued manifestation, shall follow the conditions required by the evolution of law." 20 See Bjuvberg (2015a, pp. 113, 117), Berglund (2013, p. 67), Cejie (2010, p. 89), Dahlberg (2014, p. 252), and Kleist (2012, pp. 72-73). law-makers intentions, but in 'objective' circumstances related to the law as such. ${ }^{21}$

So interpreted, the italicized proposition introducing section 3 bears on one of the founding ideas of Articles 31-33. It has far-reaching practical implications: any tax-law expert who embraces the claim without due reflection will inevitably often go astray when trying to come to grips with more concrete issues of interpretation-such as the question of whether a static or an ambulatory approach should be taken to the interpretation of tax treaties. ${ }^{22}$ The proposition can be analyzed as consisting of two assumptions: (1) Article 31 presumes a different approach to treaty interpretation than does Article 32. (2) The intentions of the parties are better reflected in supplementary means of interpretation, such as the preparatory work of the treaty, than in the text of an interpreted treaty. Both assumptions are founded on a misconception.

The ultimate purpose when interpreting a treaty, as described in Articles 31-33 of the VCLT, is to establish the intentions of the treaty parties-or more accurately, the meaning that the parties intended the treaty to communicate. ${ }^{23}$ The purpose of the treaty interpretation process is thus the same as the purpose of understanding just any verbal utterance. As long emphasized by linguistics, in order for a reader or a listener to understand a verbal utterance, he or she must assume that the speaker or writer acts rationally, that is to say, in accordance with certain standards of communication. ${ }^{24}$ When interpreting a treaty, international lawyers assume, for example, that the treaty parties conformed to the lexicon, grammar, and pragmatic rules of the language used for every authenticated version of it; ${ }^{25}$ that a consistent meaning was conferred on all

21 See Strömholm (1996, p. 453). Translation to English by the author. In Swedish, the passage reads: "En begreppsbildning, som bör omnämnas i detta sammanhang och som alltjämt ofta användes i lagtolkningsdiskussionen, är uttrycken 'subjektiv' och 'objektiv' tolkningsmetod. Mycket generellt kan det sägas, att uttrycket subjektiv brukar ges åt en metod som kännetecknas av strävan att finna och söka ledning i de syften och avsikter som faktiskt förelegat vid lagstiftningens tillkomst (det är detta betonande av den 'historiska lagstiftaren' som rättfärdigar termen 'subjektiv'). En 'objektiv metod' däremot kännetecknas av att dess förespråkare vid tolkningsproblemens lösning vill söka ledning icke i lagstiftarens avsikter utan i sådana ('objektiva') omständigheter som hänför sig till själva lagen.”

22 Cf. Linderfalk and Hilling (2015, pp. 34-59).

23 See, for example, Navigational and Related Rights (n. 18), p. 242, para. 43.

24 See, for example, Blakemore (1992).

25 See, for example, Case Concerning Kasikili/Sedudu Island (Botswana/Namibia), Judgment of 13 December 1999, ICJ Reports 1999, p. 1045, at 1062, para. 25. 
words and lexicalized phrases used in the treaty; ${ }^{26}$ that the treaty parties arranged so that the application of the treaty results in the realization of its object and purpose; ${ }^{27}$ and so forth. In linguistics, an assumption of this kind is referred to as a communicative assumption. ${ }^{28}$

Articles 31 and 32 serve to limit the interpretation process in two ways. The first limitation lies in the fact that only certain types of interpretative data may be used. Acceptable data are organized into categories; in the terminology of the Vienna Convention, categories of data correspond to means of interpretation. According to Article 31, consequently, interpreters may draw upon conventional language, the context, ${ }^{29}$ and the object and purpose of the treaty-sometimes referred to as the "primary means of interpretation." According to Article 32, interpreters may resort also to supplementary means of interpretation, including the preparatory work to the treaty and the circumstances of its conclusion. These categories of data, combined with a specific set of communicative assumptions, help interpreters come to a conclusion about the intentions of the parties.

When international lawyers interpret a treaty in accordance with Article 31, they naturally start by determining the ordinary meaning of the terms of the treaty. When the ordinary meaning is ambiguous, international lawyers turn to determining which one of the alternative ordinary meanings best coheres with the context and the object and purpose of the treaty. In other words, no interpretation according to Article 31 may possibly exceed the boundaries of conventional usage. In this respect, Article 31 differs from Article 32, which allows for more extensive interpretations,

26 See, for example, Navigational and Related Rights (n. 18), p. 239, para. 54.

27 See, for example, Kasikili/Sedudu Island (n. 25), pp. 1072-1073, para. 43.

28 See, for example, Blakemore (1992).

29 The context is considered to comprise not only the categories of data defined in Article 31, paragraph 2, but also those defined in paragraph 3. See, for example, Oppenheim's International Law (1992, p. 1274, n. 17). Cf. the ILC Commentary on the Final Draft Articles on the Law of Treaties: "[T]he word 'context' in the opening phrase of paragraph 2 is designed to link all the elements of interpretation mentioned in this paragraph to the word 'context' in the first paragraph and thereby incorporate them in the provision contained in that paragraph. Equally, the opening phrase of paragraph 3 'There shall be taken into account together with the context' is designed to incorporate in paragraph 1 the elements of interpretation set out in paragraph 3.” Report of the International Law Commission to the United Nations General Assembly, covering the work of the second part of its seventeenth and eighteenth sessions (UN Doc. A/6309/Rev.1), Yearbook of the International Law Commission (1966:2), p. 169, at 220. although only under strictly limited conditions; the condition is that the application of Article 31 leads to a "manifestly absurd or unreasonable" result. This is not to say that, ultimately, the application of Article 31 is intended to serve a different purpose than that of Article 32. For both articles, the purpose is to establish the intentions of the treaty parties. ${ }^{30}$ Anyone who claims that the application of Article 31 is intended to establish the meaning of the text of a treaty will find himself saddled with an impossible burden. He or she must explain what the concept of "the meaning" of the treaty stands for, if not the meaning that the parties to the treaty intended to communicate. ${ }^{31}$

The second limitation introduced by Articles 31 and 32 is the hierarchical organization of interpretative data. If application of Article 31 leads to a result other than that ensuing from application of Article 32, then normally the treaty shall be understood in accordance with Article 31. It is only when the application of Article 31 leads to a result, which is either ambiguous or obscure, or manifestly absurd or unreasonable, then the treaty shall be understood in accordance with Article 32. This is not to say that the text of a treaty takes priority over the intentions of the treaty parties, as all means of interpretation are used to establish party intention. The hierarchical organization of means of interpretation is instead based on the idea that when seeking to establish the intentions of the treaty parties, some means of interpretation normally provide better guidance than others. ${ }^{32}$ This is why, for example, the preparatory work of a treaty and the circumstances of its conclusion are categorized as belonging to supplementary and not primary means of interpretation. While primary means of interpretation comprise data that in one way or another hark back to the agreement existing when the treaty was given final and authenticated form, the preparatory work of a treaty and the circumstances of its conclusion always refer, by definition, to the agreement at an earlier, more preliminary stage.

30 See, for example, Oppenheim's International Law (1992, p. 1267). Cf. the ILC Commentary on the Final Draft Articles on the Law of Treaties (n. 29), p. 169, at 220: "The article as already indicated is based on the view that the text must be presumed to be the authentic expression of the intention of the parties; and that, in consequence, the starting point of interpretation is the elucidation of the meaning of the text, not an investigation ab initio into the intentions of the parties."

31 Linderfalk and Hilling (2015, p. 39).

32 Cf. The ILC Commentary on the Final Draft Articles on the Law of Treaties (n. 29), pp. 217-223. 


\section{Rules of interpretation-or guidelines?}

Articles 31-33 do not provide any rules of interpretation proper. They provide only guidelines for the interpretation process. ${ }^{33}$

"Interpretation" is a tricky word inasmuch as it can be used in several different senses. First, "interpretation" can be used to refer either to just any process of understanding of a text or to understanding obtained or attempted only under limited conditions. ${ }^{34}$ In one sense, we may say that we interpret a text every time we consciously or unconsciously confer meaning upon it. No matter how carefully a text was put together, a clear meaning cannot possibly be conferred on any of its parts until it has been interpreted. In another sense, it is only when we have already read a text and found that we are still unclear about its precise meaning that we can say that we subject it to interpretation when we subsequently proceed with our attempts at understanding it. ${ }^{35} \mathrm{~A}$ text does not always need to be interpreted, and when we interpret it, we do so to a greater or smaller degree, depending on how much of the text we previously failed to understand or succeeded in clarifying. When the Vienna Convention uses the word "interpretation", it is in the latter sense. Exceptionally clear confirmation of this fact can be found in Article 33, paragraph 4:

[W] hen a comparison of the authentic texts discloses a difference of meaning which the application of articles 31 and 32 does not remove, the meaning which best reconciles the texts, having regard to the object and purpose of the treaty, shall be adopted.

If interpretation is the only way to understand the text of a treaty, it is impossible to disclose a difference of the meaning of two or more authenticated versions without having previously applied Articles 31-32. Article 33, paragraph 4 apparently assumes that treaties can be understood even without interpretation.

Second, international lawyers can talk about the "interpretation" of treaties and be interested in two different things: knowing how a specific reader or group of readers actually came to understand the treaty in some particular way or knowing whether and how this same understand-

33 See Berglund (2013, p. 67) and Bjuvberg (2015a, p. 130.)

34 See Dascal and Wróblewski (1988, pp. 203-205).

35 Ibid. ing can be justified. ${ }^{36}$ Among international lawyers, there has been a discussion on whether the discovery of legally relevant knowledge, such as the meaning of a treaty, could ever be rationally explained. Most remain sceptical to this:

Considering the inherently individualized nature of any process of discovery, and the countless number of factors that potentially may have an influence upon it, we cannot seriously expect to find a regular pattern systematically employed in each instance of discovery by a law-applying agent of an assumed meaning of a treaty. ${ }^{37}$

In any case, in the particular context of Articles 31-33 of the VCLT, there is no doubt as to what is meant by "interpretation". When states and international judicial bodies apply Articles 31-33, it is because they are interested in establishing whether or not an assertion about the meaning of a treaty can be justified. The motive that actually generated this same assertion is for them of no material consequence.

The proposition that Articles 31-33 provide only guidelines of interpretation is based on a dual misconception. It presupposes that in the context of the Vienna Convention, "interpretation" means, first, any process of understanding of the text of a treaty and, second, the discovery of its meaning. This dependence of the proposition on a particular understanding of the word "interpretation" comes out very clearly in Martin Berglund's monograph on the avoidance of international double taxation. It is no mere coincidence that this is the work that most forcefully argues the idea that Articles 31-33 are to be seen only as a collection of guidelines. Berglund writes:

If, prior to interpretation, you wish to determine whether or not the intention was expressed in the text, this requires that you can distinguish between the text before and after interpretation. However, such a distinction cannot possibly be made. ${ }^{38}$

He continues a few pages later:

When you ask the question whether some subsequent legal development must be taken into account for purposes of interpre-

36 On the distinction between the discovery and justification of legal propositions generally, see, for example, Wasserstrom (1961, pp. 25-31) and Wroblewski (1992, pp. 14-16). On the significance of this distinction for the understanding of Articles 31-33 of the VCLT, see Linderfalk (2014b) and Linderfalk (2007b, pp. 133-154).

37 See Linderfalk (2015, p. 171).

38 See Berglund (2013, p. 68). Translation to English by the author. In Swedish, the passage reads: "Om man före tolkningen ska kunna bedöma om avsikten har uttryckts i texten krävs det att man kan skilja mellan texten före tolkning och texten efter tolkning. En sådan strikt åtskillnad låter sig dock inte genomföras.” 
tation, it has in fact been taken into account already, in the sense that it forms an element of your pre-understanding of the issue. Therefore, interpretation is necessarily dynamic, because the prevailing relationship between meaning and context is in continual flux. ${ }^{39}$

In a universe where "interpretation" is thought to mean just any process of understanding of the text of a treaty and Articles 31-33 of the VCLT are seen as a means to explain the discovery of its meaning, Berglund's observations are completely conceivable and possibly even correct. In the international legal universe that actually prevails, his observations are irrelevant.

\section{The 1966 ILC Commentary}

\author{
The ILC Commentary adopted in 1966 is of good help when \\ attempting to understand Articles 31-33. ${ }^{40}$
}

As we can see, Articles 31-33 are not entirely easy to understand and apply correctly. This seems to be in part a result of the human element: Swedish lawyers understand Articles 31-33 in the light of their collected experience of the interpretation of Swedish legislation and private law contracts. Partly, it seems to be a result of the particular design of the VCLT. To enable the adoption of a legal regime, which can be applied to treaties without having further regard to details such as subject-matter or scope, or number of parties, and which allows at the same time scope for necessary adaptation of the regulation to the particular interests and needs that may have to be satisfied in concrete cases of interpretation, Articles 31-33 have been drafted with a primary focus on means of interpretation. No one means of interpretation allows itself any inferences about the meaning of a treaty. To enable successful analysis, interpreters must combine means of interpretation with one or other communicative assumptions. The Articles, however, provide only sporadic reference that helps identify the particular communication assumptions that international law finds acceptable. For more detailed guidance, interpreters must fall back on international judicial prac- tice, which of course remains a less accessible means for the determination of law.

Because of this, Articles 31-33 themselves must often be subjected to interpretation. When tax-law scholars interpret Articles 31-33, they sometimes look for support in the extensive Commentary that the International Law Commission adopted in $1966 ;{ }^{41}$ they sometimes refer to this Commentary as "the official interpretation" or the "official explanation" of Articles 31-33. ${ }^{42}$ Of course, compared to the common practice of resorting to the work of other tax-law scholars, this is a more solid way to argue a proposition about the meaning of the VCLT. However, it would seem that the legal status of the ILC Commentary needs some explaining.

The ILC is a subsidiary organ of the UN General Assembly. Its particular task is to codify and progressively develop international law. Typically, for a very long time, this task was fulfilled following an established procedure: the Commission would list topics suitable for codification; on the basis of careful studies of relevant practice, following lengthy discussions within the Commission, the Commission would adopt a set of final draft articles, which together with an accompanying Commentary would be passed on to the General Assembly for further action. The General Assembly in turn would typically convene a diplomatic conference, which would negotiate on the basis of the ILC draft articles; it would make the necessary amendments or additions; and possibly, it would adopt a treaty that could be signed and ratified or acceded to by states. This was the procedure followed in the case of the conclusion of the VCLT.

The 1966 Commentary, together with the final draft articles adopted by the ILC, was part of the background material supplied to all Vienna Conference participants. ${ }^{43}$ While the Commentary is not as such part of the minutes of the Conference, it clearly reflects on at least parts of the long process of drafting of the Vienna Convention, and because of this, it would seem very odd not to treat it as

41 See ILC Commentary on the Final Draft Articles on the Law of Treaties (n. 29).

42 See, in turn, Dahlberg (2003, p. 150) (Sw. "den officiella tolkningen”) and Sallander (2013, p. 54 ff). (Sw. “den officiella förklaringen”). 43 Documents of the Conference, United Nations Conference on the Law of Treaties, First and second sessions, Vienna, 26 March to 24 May 1968 and 9 April to 22 May 1969, Official Records, p. 7.
39 Ibid, p. 76. Translation to English by the author. In Swedish, the passage reads: "När man ställer sig frågan om en viss senare rättsutveckling ska beaktas i den aktuella tolkningssituationen är den redan beaktad i den bemärkelsen att den utgör en del av den rättsliga bakgrundsförståelsen. Tolkning är därför med nödvändighet dynamisk eftersom meningssammanhanget ständigt ändras.”

40 See Dahlberg (2003, p. 150), Kleist (2012, p. 73 ff) and Sallander (2013, p. 54 ff). 
part of the preparatory work of the VCLT. ${ }^{44}$ This is not to say, of course, that the Commentary determines the understanding of the VCLT in the same way as preparatory work in some jurisdictions determine the meaning of taxlaw legislation. The ILC Commentary is a supplementary means of interpretation. As such, according to Article 32, it may determine the meaning of the VCLT for certain limited purposes only: (i) to confirm the meaning of Article 31-33 ensuing from a systematic analysis of conventional language, the context, and the object and purpose of the VCLT; or (ii) to determine the meaning of the Articles, when a systematic analysis of the three primary means of interpretation leads to a result, which is either ambiguous or obscure, or manifestly absurd or unreasonable. ${ }^{45}$

\section{The significance of tax-law terminology}

When you determine the ordinary meaning of a treaty, this is done primarily with the resort to the specific terminology practiced in the relevant sphere of activity governed by the treaty, such as international taxation. ${ }^{46}$

In the terminology of Article 31 of the VCLT, the "ordinary meaning" refers to the meaning conferred on the terms of a treaty in conventional language..$^{47}$ The Vienna Convention does not pay heed to the particular linguistic community in which a language pattern developed. On the contrary, if obviously the Convention presupposes that everyday language is taken into account, then any relevant tech-

\footnotetext{
44 It has to be remembered, of course, that the 1966 ILC Commentary is not the result of any action of states. ILC members are not state representatives, but act in the capacity of international law experts. Cf. Article 2 of the Statute of the International Law Commission. Consequently, the interpretative value of the Commentary would always inevitably turn on the assumption that states read and reflected upon them.

45 It may seem that I am committing here a logical fallacy: that I am suggesting that Articles 31-33 can be applied for the purpose of the interpretation of Articles 31-33. This is not so. What I am suggesting is that Articles 31-33 of the VCLT can be interpreted based on the identical rules of customary international law.

46 See Dahlberg (2003, p. 151) and Kleist (2012, pp. 74-75, 89).

47 Note that conventional language comprises not only a lexicon and a grammar, but also rules of pragmatics. On the importance of this observation, see, for example, Linderfalk (2008a, pp. 343-364) and Linderfalk (2013, pp. 241-250).
}

nical languages must be taken into account, too. ${ }^{48}$ It may be seen as something of problem, of course, that occasionally a different meaning is conferred on a term, depending on whether it is looked upon from the perspective of everyday users of a language, such as English, or users of a technical language. By "the exercise" of an employment, for example, international tax lawyers would normally understand something fairly different than would users of everyday English. Such "conflicts" between everyday language and technical parlance cannot be resolved by application of any rule of international law. In the determination of the ordinary meaning of "the exercise" of an employment, although the term may occur in the context of a tax treaty, international law still does not automatically grant precedence of the meaning normally conferred by tax lawyers over the meaning conferred in everyday language. ${ }^{49}$ In situations such as these, you must simply accept the conclusion that the ordinary meaning is ambiguous. This being your point of departure, you must continue your interpretation efforts and investigate whether possibly the context or the object and purpose of the treaty helps excluding the one or the other ordinary meaning..$^{50}$

\section{Articles 31-33 apply unless treaty parties agree otherwise}

\section{If the parties to a tax treaty reach an agreement} concerning its interpretation, then the agreement can be used as a means of interpretation, based either on Article 31, paragraph 2, lit. a or b, or Article 31, paragraph 3, lit. a; this applies even when the agreement is binding under international law. ${ }^{51}$

There is something contradictory about this assumption. If, on the one hand, the parties to a tax treaty enter into an agreement concerning its interpretation, and this agreement is binding under international law, naturally, the agreement applies. There is no need to invoke any particular provision of the Vienna Convention. The parties to the treaty must apply the interpretative agreement, irre-

48 See, for example, Young Loan Arbitration (Belgium, France, Switzerland, the UK and the USA v. FRG), Award of 16 May 1980, International Law Reports, Vol. 59, p. 495, at 530-531, para. 18.

49 Cf. Guinea - Guinea-Bissau Maritime Delimitation, Award of 14 February 1985, International Law Reports, Vol. 77, p. 636, at 662 ff., paras. $46 \mathrm{ff}$.

50 Ibid.

51 See Kleist (2012, p. 108 ff) and Sallander (2013, p. 55). 
spective of whether or not the agreement can be used as a means of interpretation, in the sense of Articles 31-33, based on any of the particular provisions that they contain..$^{52}$ After all, Articles 31-33 are ius dispositivum-just like everything else contained in the Vienna Convention (and most of international law, for that matter). If, on the other hand, you have established that an interpretative agreement comes within the scope of application of Article 31, paragraphs 2 or 3, the agreement remains just one piece of data among many having a possible bearing on the treaty interpretation process. The interpretative agreement is allowed to inform the interpretation process, but it is not necessarily the decisive factor that determines once and for all the meaning of the interpreted treaty. The proposition giving significance to an interpretative agreement under Article 31, paragraphs 2 and 3 would seem to be based on a misconception of the nature of Articles 31-33. An interpretative agreement cannot be regarded as just any means of interpretation and serve, at the same time, as the decisive factor in the determination of the meaning of a treaty.

\section{The special meaning (Article 31, paragraph 4)}

\section{The special meaning of the terms of a treaty is a means of interpretation that can be used in exactly the same way as any other means of interpretation. ${ }^{53}$}

According to Article 31, paragraph 4, "a special meaning shall be given to a term if it is established that the parties so intended." Many tax-law scholars would seem to think that the special meaning of a term in a treaty amounts to very much the same as the meaning conferred upon it in the relevant technical language, in this case, the parlance of international tax lawyers. If, for example, a commentary to the Organization for Economic Cooperation and Development (OECD) Model Convention indicates that among international tax lawyers, "the exercise of an employment" means something else than it does among users of everyday English, then, as the argument goes, Article 31, paragraph 4, provides a basis for interpreting the term in the light of tax-law parlance rather than everyday language.

52 See, for example, Legal Consequences for States of the Continued Presence of South Africa in Namibia (South West Africa) notwithstanding Security Council Resolution 276 (1970), Advisory Opinion of 21 June 1971, ICJ Reports 1971, p. 22, paras. 21-22.

53 See Bjuvberg (2015a, p. 117), Dahlberg (2014, p. 252), Dahlberg (2003, p. 153), Kleist (2012, p. 90) and Sallander (2013, p. 55).
This argument is based on a misunderstanding. In the terminology of the Vienna Convention, "special meaning" refers to just any meaning that cannot immediately be inferred from conventional language. ${ }^{54}$ What Article 31, paragraph 4, establishes is nothing more than a burden of proof: if a person advances the suggestion that the ordinary meaning of a treaty does not agree with the intentions of its parties, then it lies upon this person to substantiate his suggestion. ${ }^{55}$ Justification must be sought in Articles 31-33-as always when establishing the intentions of treaty parties. Consulting the context, the object and purpose of the treaty, and the supplementary means of interpretation, the interpreter must find support for a different interpretation than the one that immediately follows from conventional language-whether those other means imply a preference for one of the two ordinary meanings, or the adoption of a neologism falling outside completely of the extension of the ordinary meaning. Article 31, paragraph 4, does not as such provide support for the resort to any particular category or categories of interpretative data. The provision presupposes the application of other provisions of the VCLT. If Articles 31 and 32 provide support for conferring on a tax treaty term a technical meaning rather than a meaning following from everyday language, then this is due to those other provisions, and not to Article 31, paragraph 4.

54 Cf. Draft Article 71 as provisionally adopted by the ILC in 1964: "Article 71. Terms having a special meaning. Notwithstanding the provisions of paragraph 1 of Article 69, a meaning other than its ordinary meaning may be given to a term if it is established conclusively that the parties intended the term to have that special meaning." Draft Articles on the Law of Treaties, Report of the International Law Commission covering the work of its sixteenth session, Yearbook of the International Law Commission, 1964, Vol. 2, p. 174, at 199.

55 See e.g. AAPL v. Sri Lanka, Award of 27 June 1990, International Law Reports, Vol. 106, p. 439, para. 40: "In the interpretation of treaties ... we ought not to deviate from the common use of the language unless we have very strong reasons for it.” 


\section{The scope of supplementary means of interpretation}

\author{
Article 32 contains a short list of the means of \\ interpretation that can be used based on this same \\ provision. The list is not exhaustive, which means that in \\ principle, any interpretative data may be used. ${ }^{56}$
}

While Article 32 provides examples of what shall be regarded as coming within the scope of "supplementary means of interpretation," it does not provide any exhaustive definition of the concept-the wording of the provision makes this abundantly clear. According to Article 32, consequently, lawyers may apply for the purpose of the interpretation of a treaty: supplementary means of interpretation, "including the preparatory work of the treaty and the circumstances of its conclusion." just any interpretative data may be used to inform the interpretation process. "[S] upplementary means of interpretation" refers back to customary international law. ${ }^{58}$ Just as with Article 31-which, in order to be comprehensible, must be read in light the communication assumptions that authoritative interpreters apply-Article 32 must be understood in light of the practice and opinio juris of states, possibly as confirmed by the practice of international judicial bodies. Put differently, in order for a category of interpretative data to be classified as a supplementary means of interpretation, it must be recognized as such by states. ${ }^{59}$

56 See Berglund (2013, pp. 67-68), Bjuvberg (2015a, p. 117) and Dahlberg (2014, p. 252).

57 Italics are added.

58 I have argued this proposition extensively elsewhere. See Linderfalk (2007a, p. 238-239).

59 Here are some examples of rules of interpretation and categories of interpretative data used by international judicial fora invoking Article 32: "the rule of necessary implication," Bosnia Genocide (Bosnia and Herzegovina v. Serbia and Montenegro, Merits, Judgment of 26 February 2007, ICJ Reports 2007, p. 113, para. 166; treaties in pari materia, Oil Platforms (Iran v. the USA), Preliminary Objections, Judgment of 12 December 1996, ICJ Reports 1996, pp. 814-815, para. 29; the principle of unius est exclusio alterius, Navigational and Related Rights (n. 18), p. 241, para. 61; the principle of ejusdem generis, Grimm v. Iran, Decision of 18 February 1983, International Law Reports, Vol. 71, para. 652; and "the rule of restrictive interpretation", Navigational and Related Rights (n. 18), pp. 236-237, para. 48.

\section{The significance of the OECD Model Convention and Commentaries}

In the interpretation of tax treaties concluded by Sweden with other states, interpreters may use as a means of interpretation the OECD Model Tax Convention on Income and on Capital with Commentaries, based on either Article 31, paragraph 2, lit. b, or Article 31, paragraph 3, lit. c. ${ }^{60}$

The OECD works to promote increased harmonization of international tax regulations. As early as 1963, the OECD Committee on Fiscal Affairs (CFA) adopted a Model Tax Convention on Income and on Capital, including a set of extensive Commentaries. Since then, both the Model and the Commentaries have been updated and revised, with increasing frequency.

That the OECD Model and Commentaries can be used to inform interpretation of tax treaties is nowadays taken for granted by Swedish administrative courts. ${ }^{61}$ This begs the question of whether the assumption can be justified under international law. Given that the Model and Commentaries are not legally binding, ${ }^{62}$ what precise provision or provision in Articles 31-33 allow Swedish courts to consult them - if such support ever exists? ${ }^{63}$ The question is thoroughly relevant, contrary to what some tax-law scholars have argued. ${ }^{64}$ In a process of interpretation concerned with the meaning of a tax treaty, depending on whether the required support is found in Article 31 or Article 32,

60 Dahlberg (2003, pp. 152-153).

61 See, for example, RÅ 1996 ref. 84.

62 In principle, of course, there is nothing to prevent OECD member states from developing special rules for the interpretation of tax treaties concluded by them between themselves. Articles 31-33 are ius dispositivum. They apply only insofar and to the extent that parties to a treaty have not agreed otherwise.

63 The Vienna Convention does not assign any great significance to whether or not a piece of interpretative data demonstrates the existence of a norm that is binding under international law. Consequently, as an international law scholars, I find it strange to refer (as tax-law experts often do) to the significance of the OECD Model Convention and Commentaries as "sources of law" (Sw. "rättskälla"). See, for example, Bjuvberg (2015a), Cejie (2010, pp. 87, 90, 92-93), Dahlberg (2003) and Sallander (2013, pp. 59-61). If you accept the idea that the Model and Commentaries are not themselves binding under international law, then with the terminology to which I am accustomed, they cannot possibly be sources of any law. For the same reason, I find it irrelevant to inquire whether the Model and Commentaries can be categorized as "soft law" or not. See, for example, Bjuvberg (2015a, pp. 116-117). 64 See Berglund (2013, pp. 73-74). 
the OECD Model and Commentaries will be given a completely different significance. My colleague Maria Hilling, Associate Professor of Tax Law, and I have published an extensive article on the topic. ${ }^{65}$ Our conclusion is that no general answer can be given to the question as posed. Depending on the particular textual element to be interpreted, and the particular line of argument to be pursued, different grounds of justification may be applicable:

- The OECD Model and Commentaries may help determine the ordinary meaning of the terms of a tax treaty, ${ }^{66}$ or its object and purpose, in the sense of in the sense of Article 31, paragraph 1.

- The OECD Model and Commentaries may come within the scope of application of Article 31, paragraph 3, lit. b, either because they give report of the interpretation and application of tax treaties generally or because they themselves form part of a "subsequent practice," in the sense of this same provision.

- It can be established that a tax treaty was drafted on the basis of an OECD Model or a particular version of the attached Commentaries, the Model or the Commentaries may form part of the circumstances of the conclusion of the tax treaty, in the sense of Article $32 .{ }^{67}$

Professor Mattias Dahlberg has suggested two additional grounds that may serve to justify a use of the OECD Model Convention and Commentaries. First, as Dahlberg proposes, "the OECD Commentaries could possibly, at least partly, be considered as belonging to the relevant rules of international law referred to in [Art. 31, para. 3] lit. c." ${ }^{68}$ Myself, I am sceptical to this suggestion, primarily because of the communicative assumption that in each and every particular case would serve to justify application of Article 31, paragraph 3, lit. c. According to this provision, in the interpretation of a treaty, consideration shall be had to "[a]ny relevant rules of international law applicable in the relations between the parties." When rules of international law are used for the purpose of the interpretation of a treaty, it is the assumption that treaty parties ar- ranged so that the treaty does not derogate from any other international norm applicable in the relationship between them. ${ }^{69}$ This assumption-if not the mere wording of Article 31, paragraph 3, lit. c-implies the existence of a specific requirement: in order for a rule to come within the scope of application of Article 31, paragraph 3, lit. c, it must be derived from any of the recognized sources of international law. ${ }^{70}$ This requirement would seems to preclude all use of the OECD Model and Commentaries.

Second, as Dahlberg submits, the OECD Model and Commentaries could possibly be used as a means of interpretation based on Article 31, paragraph 2, lit. b, which instructs interpreters to consider, for the purpose of the interpretation of a treaty, "any instrument which was made by one or more parties in connexion with the conclusion of the treaty and accepted by the others parties as an instrument related to the treaty.” This suggestion fails to convince for three reasons. First, the OECD Model and Commentaries are not made by any party to a tax treaty but by an organ of an international organization. Second, the OECD Model and Commentaries are not made in connection with the conclusion of a tax treaty, in the sense of Article 31, paragraph 2, lit. b. Third-and perhaps most important-irrespective of the particular tax treaty considered, it will be exceptionally difficult to demonstrate that the OECD Model and Commentaries were accepted by the parties as an instrument related to the treaty. Comparison can be made with treaty reservations, which serve as a classic example of instruments coming within the scope of application of Article 31, paragraph 2, lit. b. ${ }^{71}$ It is no mere coincidence that Article 31, paragraph 2, lit. b, uses the word "instrument"-it is precisely in the instrument of ratification or accession that we will normally find reservations when made by a party to a treaty. Practical considerations suggest that reservations may sometimes be relevant in the application of Article 31, paragraph 2, lit. b, but only because of the presumption laid down in Article 20, paragraph 5, of the VCLT:

[U]nless the treaty otherwise provides, a reservation is considered to have been accepted by a State if it shall have raised no ob-
65 See Linderfalk and Hilling (2015).

66 See, in the same vein, Dahlberg (2003, p. 151).

67 See, in the same vein, Kleist (2012, p. 93): "[T] hey can be regarded as 'circumstances of its conclusion', insofar as they were present at the time of the conclusion of the treaty."

68 See Dahlberg (2003, p. 153): "Enligt min mening skulle kommentaren till OECD:s modellavtal åtminstone i någon mån kunna hänföras till sådana internationella rättsregler som det refereras till i c)."
69 See, for example, Award in the Arbitration regarding the Iron Rhine ("Ijzeren Rijn") Railway between the Kingdom of Belgium and the Kingdom of the Netherlands, Decision of 24 May 2005, UNRIAA, Vol. 27, p. 35, at pp. 72-73, para. 79.

70 For a definition of the concept of a recognized source of international source, see, for example, the Statue of the International Court of Justice, Article 38, paragraph 1, lit. a, b and c.

71 See, for example, McRae (1979, pp. 189-170) and Villiger (1986, p. 344). 
jection to the reservation by the end of a period of twelve months after it was notified of the reservation or by the date on which it expressed its consent to be bound by the treaty, whichever is later.

There is no corresponding presumption that can be applied to the OECD Model and Commentaries.

\section{Ambulatory or static interpretation?}

Whether an ambulatory or a static approach shall be taken to the interpretation of tax treaties can be stated in the form of one or several general principle. ${ }^{72}$

The question whether an ambulatory or a static approach shall be taken by interpreters when applying Articles 3133 has long been discussed among international lawyers. ${ }^{73}$ Many of the categories of interpretative data approved by the VCLT lend support for both the competing positions. For example, as Article 31 reads, "the ordinary meaning" of a treaty could be determined using the conventional language existing at the time of its conclusion, or the conventional language existing at the time of interpretation. A "subsequent practice" could be used to establish either what the parties to the treaty originally understood by a term or provision or what the parties have gradually come to understand along the way when putting the term or provision into practice. Similarly, "relevant rules of international law" (Article 31, paragraph 3, lit. c) could be understand as a reference to either the rules applicable between the parties at the time of the conclusion of a treaty or the rules applicable at the time of interpretation.

How do you approach open-ended treaty language such as this? Tax-law literature published in Sweden demonstrates attempts to answer this question by the laying down of general principles of shifting contents, directed often as a response to a very particular issuethat concerning which of several consecutive versions of the Commentaries to the OECD Model Convention should be used for the purpose of the interpretation of a tax treaty. For example, in line with express recommendations of the CFA, literature often makes a distinction between "changes to the Commentaries that are a direct con-

72 See Cejie (2010, pp. 93-96) and Dahlberg (2003, pp. 144-145, 151152).

73 See, for example, Bjørge (2014), Higgins (1996, pp. 173-181), Linderfalk (2008b, pp. 109-141) and Waldock (1981, pp. 535-547). sequence of amendments of articles in the Model Convention," on the one hand, and "changes and additions to the Commentaries that serve either as clarifications or additions to unchanged articles in the Model," on the other hand. ${ }^{74}$ In international law, however, little support can be found for the application of general principles of this kind.

When the Vienna Convention uses terms that do not provide a direct answer to the question of whether modern or historical language shall be consulted when determining the ordinary meaning of a treaty, for example, this is the result of a deliberate drafting strategy. The parties to the Vienna Convention have decided to leave this matter to be decided by interpreters at their discretion, on a case-by-case basis. ${ }^{75}$ The principle of good faith serves as a limit to the exercise of any such discretion. ${ }^{76}$ The principle of good faith stands for the idea of international law as a purposive endeavor. ${ }^{77}$ The particular purpose set for the treaty interpretation process-to determine the intentions of the treaty parties-not only explains the substance of the international rules of treaty interpretation; furthermore, it serves to restrict the exercise of any discretionary power conferred upon interpreters under the Vienna Convention. ${ }^{78}$ Assume, for example, that a court must establish the ordinary meaning of an expression (U) used in a treaty (T) and that a choice must be made by the court between resorting to modern or historical language. As the principle of good faith insists, the question to be answered is this: is there reason to assume that in concluding $\mathrm{T}$, the parties intended the meaning of the expression $U$ to be defined by the conventions of language existing at the time of conclusion of $\mathrm{T}$ rather than the conventions existing at each and every occasion of its interpretation, or is there reason to assume the opposite to be the case? Relevant reasons could possibly be described in terms of general indicators, such as the overall purpose of the interpreted treaty

74 See Dahlberg (2003, pp. 144-145).

75 Cf. the ILC Commentary on the Final Draft Articles on the Law of Treaties (n. 29), p. 222, with regard to the provision that then corresponded to final Article 31, paragraph 3, lit. c: “[The Commission] considered that, in any event, the relevance of rules of international law for the interpretation of treaties in any given case was dependent on the intentions of the parties, and that to attempt to formulate a rule covering comprehensively the temporal element would present difficulties. It further considered that correct application of the temporal element would normally be indicated by interpretation of the term in good faith."

76 Cf. Article 26 of the VCLT: "Every treaty in force is binding upon the parties to it and must be performed by them in good faith."

77 See Linderfalk (2014a).

78 Ibid. 
or its intended life span..$^{79}$ However, this is not tantamount to concluding once and for all that any question concerning a choice between modern and historical language can be resolved by applying some or other generally purporting principle. The conclusive choice will always have to be made on the balance of all relevant reasons, and this act of balancing can be carried out relative only to each particular case.

\section{The significance of preparatory work originating in domestic law-making processes}

\author{
Articles 31-33 do not allow consideration of work done \\ within Sweden in the course of preparing for incorporation \\ of tax treaties into domestic law. ${ }^{80}$
}

Because Article 32 of the VCLT defines the concept of "supplementary means of interpretation" by bluntly and generically referring back to whatever customary rules of treaty interpretation exist at each and every moment of interpretation, it can be of interest to know that international courts and tribunals sometimes use as supplementary means of interpretation preparatory work produced in the course of domestic law-making processes. ${ }^{81}$ In most cases, when such domestic preparatory work has been resorted to, it has been for the purpose of the interpretation of bilateral treaties. ${ }^{82}$ Consequently, it would seem incorrect to generally rule out that Swedish preparatory work can be consulted when interpreting tax treaties concluded by Sweden with other states, based on Article 32. At the same time, we must still be careful so that in particular cases Swedish preparatory work is not given too much importance. In contrast to when the preparatory work of

79 See Linderfalk and Hilling (2015, pp. 54-58).

80 See Cejie (2010, p. 89) and Sallander (2013, p. 55).

81 See, for example, Case Concerning Oil Platforms (Islamic Republic of Iran v. United States of America), Preliminary Objections, Judgment of 12 December 1996, ICJ Reports 1996 (II), p. 803, at 814-815, para. 29; Beagle Channel Arbitration (Argentina v. Chile), Award of 18 February 1977, International Law Reports, Vol. 52, p. 93, at 186; Maritime Delimitation in the Area between Greenland (Denmark v. Norway), Judgment of 14 June 1993, ICJ Reports 1993, p. 51, para. 29; Guinea - GuineaBissau Maritime Delimitation (n. 49), p. 669, para. 70.

82 In at least one case, the use of domestic preparatory work concerned the interpretation of a trilateral treaty-the North American Free Trade Agreement (NAFTA). See S.D. Myers v. Canada, Award of 13 November 2000 (Partial), International Law Reports, Vol. 121, p. 73 , at 140 , para. 62 . a treaty is consulted, a supporting premise is always required. In any particular case where Swedish preparatory work can be said to demonstrate the understanding of the Swedish Government of a treaty term, it still remains to be shown that the other party to the treaty understood it in precisely the same way.

\section{Concluding observations: the virtues of cross-disciplinary dialogue}

As traditionally conceived, law consists of many different branches: civil law, constitutional law, penal law, procedural law, international law, and so on. It is appropriate to think of these different branches of law as different communities of practice. Different branches of law recognize the relevance of partly different sets of data and use partly different methodologies. Similarly, each branch of law has a partly different ethos-if you specialise in criminal law, for example, you will take a partly different perspective on legal data than will civil law colleagues; you will probably also adopt a partly different set of fundamental assumptions. At the same time, of course, branches of law are not tightly separated units, considering what they purport to govern and aim to achieve. As lawyers sometimes tend to forget, the habit of referring to the law that courts and administrative authorities bring to bear on the resolution of disputes in terms such as "criminal law" or "civil law" is merely a way of simplifying structured legal thinking. In reality, legal elements interact in the sense that often any proper understanding of, say, criminal law elements presupposes an understanding of elements traditionally identified with other branches of law. This is why, occasionally, the ambition of legal scholars to understand law and legally relevant data gives them reason to think across branches.

Accepting the identity of tax law and international law as different communities of practice, when tax-law research is brought to bear on international law, as for example, when it raises issues of treaty interpretation, that research is cross-disciplinary in nature. It is not terribly different from legal research drawing heavily on non legal disciplines such as linguistics, psychology, sociology, or feminist theory. I think it is important that this nature of the research is fully acknowledged, for the sake of its success. Thinking across disciplines can certainly be a very good way of bringing about new knowledge. At the same time, as thinking will have to be done in a context that re- 
searchers are not perfectly at home with, it can be terribly challenging. Cross-disciplinary research, to be truly successful, requires a willingness and an ability of the scholar performing it to adapt to a different mind-set; it requires at least some appreciation of data, with which previously he or she may have been wholly unfamiliar. In the case of taxlaw research drawing heavily on the international law on treaty interpretation, a successful outcome assumes more particularly that scholars allow themselves necessary time to fully assimilate both the theory of treaty interpretation and the rich practice developed by international judicial bodies over the past 50 or so years.

This observation brings me back to my earlier call for cross-disciplinary dialogue. As I see it, tax-law scholars interested in learning more about tax treaty interpretation have clear reason to collaborate with colleagues specializing in international law. Conversely, of course, international law scholars interested in learning more about treaty interpretation in a tax-law context have reason to consult with tax-law expertise. The reason for such new initiatives lies partly in the virtues of cross-disciplinary research and partly in the virtues of dialogue. Consequently, cross-disciplinary dialogue will not only help to bring the discussion on tax treaty interpretation entertained in the camp of Swedish tax-law expertise on a more constructive course. In an increasingly perplexing legal universe characterized by rapid developments, bringing more or less daily a new set of issues to the researchers' agenda, crossdisciplinary dialogue will also be cost-efficient. It will bring new knowledge at the minimum cost or effort.

\section{References}

Berglund, Martin. 2013. Avräkningsmetoden

Bjuvberg, Jan. 2015. "Rättskällevärdet av OECD:s modellavtal - synen på förhållandet mellan modellavtalet och Wienkonventionen i litteraturen". Svensk skattetidning (2015:2): 111-130, cited as “Bjuvberg, 2015a"

Bjuvberg, Jan. 2015. "Betydelsen av OECD:s modellavtal vid tolkningen av skatteavtal - några typfall”. Svensk Skattetidning (2015:5): 427-443, cited as "Bjuvberg, 2015b"

Bjørge, Eirik. 2014. The Evolutionary Interpretation of Treaties

Blakemore, Diane. 1992. Understanding Utterances. Introduction to Pragmatics

Cejie, Katia. 2010. Utflyttningsbeskattning av kapitalökningar

Dahlberg, Mattias. 2003. "Vilket rättskällevärde har kommentarerna till OECD:S modellavtal?". In Festskrift till Gustav Lindencrona, edited by Arvidsson, Richard et al., 137-155

Dahlberg, Mattias. 2014. Internationell beskattning, $4^{\text {th }}$ edition

Dascal, Marcelo and Wróblewski, Jerzy. 1988. "Transparency and Doubt: Understanding and Interpretation in Pragmatics and in Law", Law and Philosophy, 7: 203-205
Higgins, Rosalyn. 1996. "Some Observations on the Inter-Temporal Rule in International Law”. In Essays in Honour of Krzystof Skubiszewski, edited by Makarczyk, Jerzy, 173-181

Hilling, Maria. 2014. "Skatteavtalstolkning enligt svensk rätt", Svensk skattetidning, 2014: 322-340

Kleist, David. 2012. Methods for the Elimination of Double Taxation under Double Taxation Treaties

Linderfalk, Ulf. 2007. On the Interpretation of Treaties. The Modern International Law as Expressed in the 1969 Vienna Convention on the Law of Treaties, cited as "Linderfalk, 2007a"

Linderfalk, Ulf. 2007. "Is the Hierarchical Structure of Articles 31 and 32 of the Vienna Convention Real or Not? Interpreting the Rules of Interpretation". Netherlands International Law Review, 65: 133154, cited as "Linderfalk, 2007b"

Linderfalk, Ulf. 2008. "Who are 'the parties'? Article 31 § 3(c) of the 1969 Vienna Convention, and the 'Principle of Systemic Integration' Revisited”. Netherlands International Law Review, 55: 343364, cited as "Linderfalk, 2008a"

Linderfalk, Ulf. 2008. "Doing the Right Thing for the Right Reason: Why Dynamic or Static Approaches Should be Taken in the Interpretation of Treaties". International Community Law Review, 10: 109-141, cited as "Linderfalk, 2008b"

Linderfalk, Ulf. 2013. "Spyridon Roussalis v. Romania: Investor Consent to ICSID Arbitration, and the Limits of Treaty Interpretation". International and Comparative Law Quarterly, 62: 241-250

Linderfalk, Ulf. 2014. "The Concept of Treaty Abuse: On the Exercise of Legal Discretion", posted at the SSRN, on 17 November 2014. Available at SSRN: http://ssrn.com/abstract $=2526051$, cited as “Linderfalk 2014a"

Linderfalk, Ulf. 2014. "AJIL Symposium: Is the Vienna Convention Hostile to Drafting History? A Response to Julian Davis Mortenson, Part 2", posted at opiniojuris, on 5 February 2014. Available at: http://opiniojuris.org, cited as "Linderfalk 2014b"

Linderfalk, Ulf and Hilling, Maria. 2015 "The Use of OECD Commentaries as Interpretative Aids: The Static/Ambulatory-Approaches Debate Considered from the Perspective of International Law". Nordic Tax Journal (2015:1), 34-59

Linderfalk, Ulf. 2015. "Is Treaty Interpretation an Art or a Science? International Law and Rational Decision Making”. European Journal of International Law, 26: 169-189

McDade, Paul. 1986. "The Effect of Article 4 of the Vienna Convention on the Law of Treaties 1969". International and Comparative Law Quarterly, 35: 499-511

McRae, Donald. 1979. "The Legal Effect of Interpretative Declarations". British Yearbook of International Law, 49: 155-173

Oppenheim's International Law. 1992. Edited by Jennings, Robert and Watts, Arthur, Vol. 1, $9^{\text {th }}$ edition

Sallander, Ann-Sophie. 2013. Ömsesidiga överenskommelser enligt skatteavtal

Strömholm, Stig. 1996. Rätt, Rättskällor och rättstillämpning, $5^{\text {th }}$ edition

Thirlway, Hugh. 1972. International Customary Law and Codification Villiger, Mark. 1986. Customary International Law and Treaties

Waldock, Humphrey. 1981. "The Evolution of Human Rights Concepts and the Application of the European Convention on Human Rights". In Mélanges Offert à Paul Reuter, edited by Gross, André, 535-547

Wasserstrom, Richard. 1961. The Judicial Decision

Wroblewski, Jerzy. 1992. The Judicial Application of Law 